\title{
MIOCENE AND PLIOCENE SEDIMENTS DREDGED FROM THE SEA FLOOR OFF ST HELENS, NORTHEASTERN TASMANIA
}

\author{
by Patrick G. Quilty
}

(with two text-figures, two tables and two plates)

QUILTY, P.G., 1985 (31:vii): Miocene and Pliocene sediments dredged from the sea floor off St Helens, northeastern Tasmania. Pap. Proc. R. Soc. Tasm., 119:93-101, pls 2. https://doi.org/10.26749/rstpp.119.93 ISSN 0080-4703. Antarctic Division, Department of Science, Kingston, Tasmania.

Calcarenites dredged from 807 and $960 \mathrm{~m}, 50 \mathrm{~km}$ southeast of St Helens, Tasmania, have yielded Early Miocene and mid-Pliocene foraminiferid faunas. The Miocene fauna is a deeper water continental shelf type of the same age (N4/5) as other sediments well known from the northern coast of Tasmania. It contains a higher percentage of planktic forms than known in coeval sediments elsewhere in Tasmania. The mid-Pliocene (approximately N20) including a significant planktic component, is the first such fauna documented from Tasmania.

Key Words: Miocene, Pliocene, foraminifera, Tasmania.

\section{INTRODUCTION}

Very little is known of the CretaceousCainozoic geological history of southeastern Australia marginal to the Tasman Sea apart from the results of the studies of onshore sections by Carter (1964) and the extensive summary by Abele et al. in Douglas and Ferguson (1976) of the Gippsland Basin Tertiary. In eastern Tasmania, the only Tertiary foraminiferids studied are those from Great Mussel Roe Bay and the islands of the Furneaux Group by Quilty (1972) who recognised only Early Miocene (possibly latest Oligocene in Great Mussel Roe Bay).

Thus there is a marked gap in knowledge concerning development of oceanic circulation patterns, water temperature changes in the oceans and results of onshore drainage since sometime in the Cretaceous, although generalised evolution of these a spects has been addressed by Deighton et al. (1976), Edwards (1975) and Kennett et al. (1975).

Two new sample locations have been identified by fortuitous recovery of sedimentary rocks from the sea floor during trawling operations by the Tasmanian Fisheries Development Authority, some $30 \mathrm{~km}$ offshore, approximately $50 \mathrm{~km}$ southeast of St Helens (fig 1 ) and $130 \mathrm{~km}$ south-southeast of the closest known marine Tertiary samples from submarine outcrops in Great Mussel Roe Bay.

Australian Tertiary Stage terminology, as summarised by Abele in Douglas and Ferguson (1976), includes in the Pliocene the early part of the Cheltenhamian, the Kalimnan and the Werrikooian. Most of the Pliocene so far studied is from shallow

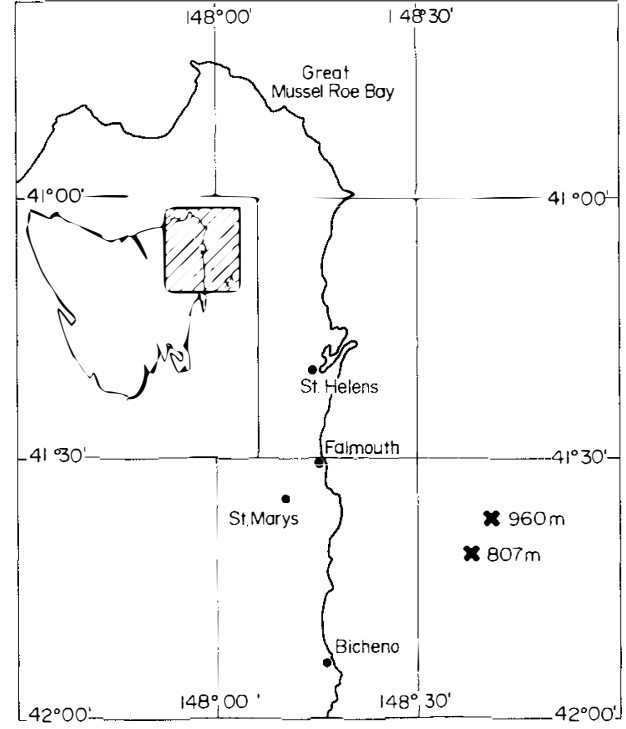

FIG. 1 - Location of samples

water sections containing characteristic benthic forms. The new Tasmanian sample is a deeper water sediment, lacking the characteristic benthic foraminiferids, but including a planktic fauna probably representing the total diversity living in the area at an instant in the Pliocene. Thus Australian stage terminology is not readily applicable to the Pliocene recorded here. 


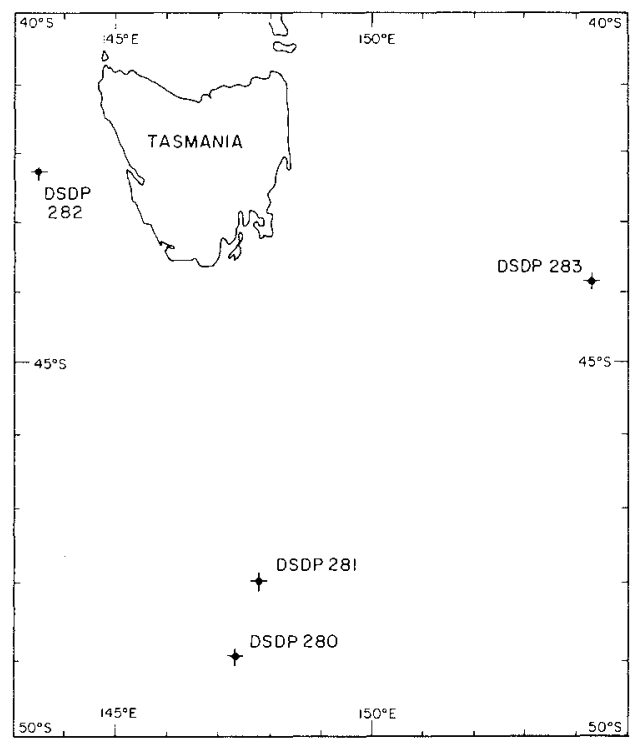

FIG. 2 - Locality map showing Deep Sea Drilling Project sites

Contemporaneous faunas of New Zealand are well known through such works as Hornibrook (1961) and Jenkins (1971).

Five Deep Sea Drilling Project sites can be regarded as close to Tasmania. They are site 280.283 (fig. 2) and 284 some $300 \mathrm{~km}$ west of the northern tip of the South Island of New Zealand. Early Miocene sections, equivalent to that recorded are found in the following drill-holes: Site 281, 93- $119 \mathrm{~m}$ (lower part); Site 282, 9 $55 \mathrm{~m}$ (lower part); Site $283,10-19 \mathrm{~m}$ (?). The only Pliocene sections equivalent to that recorded here, are found at Site 283, somewhere in the interval $0-0.5 \mathrm{~m}$ and particularly in site 284 (approximately $110-140 \mathrm{~m}$ ).

Specimens of the rocks and figured specimens are housed at the Geology Department, University of Tasmania and accession numbers are listed in the plate explanations.

\section{NEW MATERIAL}

The samples come from the following locations:-

A $41^{\circ} 40.8^{\prime} \mathrm{S}: \quad 148^{\circ} 38.6^{\prime} \mathrm{E}$ water depth $807 \mathrm{~m}$

B $41037 \mathrm{~S}: 148^{\circ} 42^{2}$ water depth $960 \mathrm{~m}$

They are thus from the present day continental slope and are taken to represent outcrops of Tertiary sediment on the seafloor.
Two lithologies and two environments are represented. It is unknown which rock type comes from which locality. The lithologies are: 1. Pale grey, fine-grained, poorly-sorted, somewhat consolidated bryozoal calcarenite; 2 . Yellowish, ferruginous, medium to coarse-grained, well-sorted, friable bryozoal calcarenite.

The rocks have a very different appearance, suggesting very different marine environments of deposition and this is supported by study of the fora miniferids which shows that the rocks formed at quite different times and environments.

\section{RESULTS \\ Pale grey, fine-grained calcarenite (sample 1 above) \\ Age}

\section{Planktic foraminiferid basis.}

The sample contains a very numerous planktic component but diversity is low and the fauna is predominantly of species of Globigerina (table 1). Jenkins (1971) studied the distribution of planktic foraminiferids from New Zealand and is thus the only author who has attempted a comprehensive review of the planktic foraminiferid faunas from sections of rocks of comparable age in a nearby locality.

The main diagnostic forms present are Globoquadrina dehiscens dehiscens (Chapman, Parr and Collins), Globigerina woodi woodi Jenkins $G$. w. connecta Jenkins, G. labiacrassata Jenkins, Globigerinoides quadrilobatus immaturus LeRoy and Globorotalia (Turborotalia) nana Bolli. It has been difficult to identify the specimens uniquely in every case even though preservation is good, and a large part of the fauna has been assigned to intermediate forms in the $G$. w. woodi$G$. w. connecta plexus. The identification of $\mathrm{G}$. labiacrassata seems a little a nomalous, particularly as it makes up a significant part of the fauna. It may be that other authors would include all such specimens in $G$. woodi. However the specimens recovered here seem typical morphotypes and as noted by Kennett and Srinivasan (1984), there is a strong phylogenetic link between the species. A degree of subjectivity is involved in their differentiation.

The age of the fauna is taken on planktic forms alone, to be Early Miocene, Globigerinaw. woodi or G. w. connecta Zones of Jenkins (1971) or approximately $\mathrm{N} 4$ or $\mathrm{N} 5$ (Globigerinoides quadrilobatus primordius/Globorotalia kugleri Zone or Globoquadrina dehiscens praedehiscens- $G$. dehiscens dehiscens Zone) of the scheme proposed by 


\section{TABLE 1 \\ SPECIES RECORDED FROM EARLY MIOCENE SEDIMENT \\ Benthic Foraminiferids}

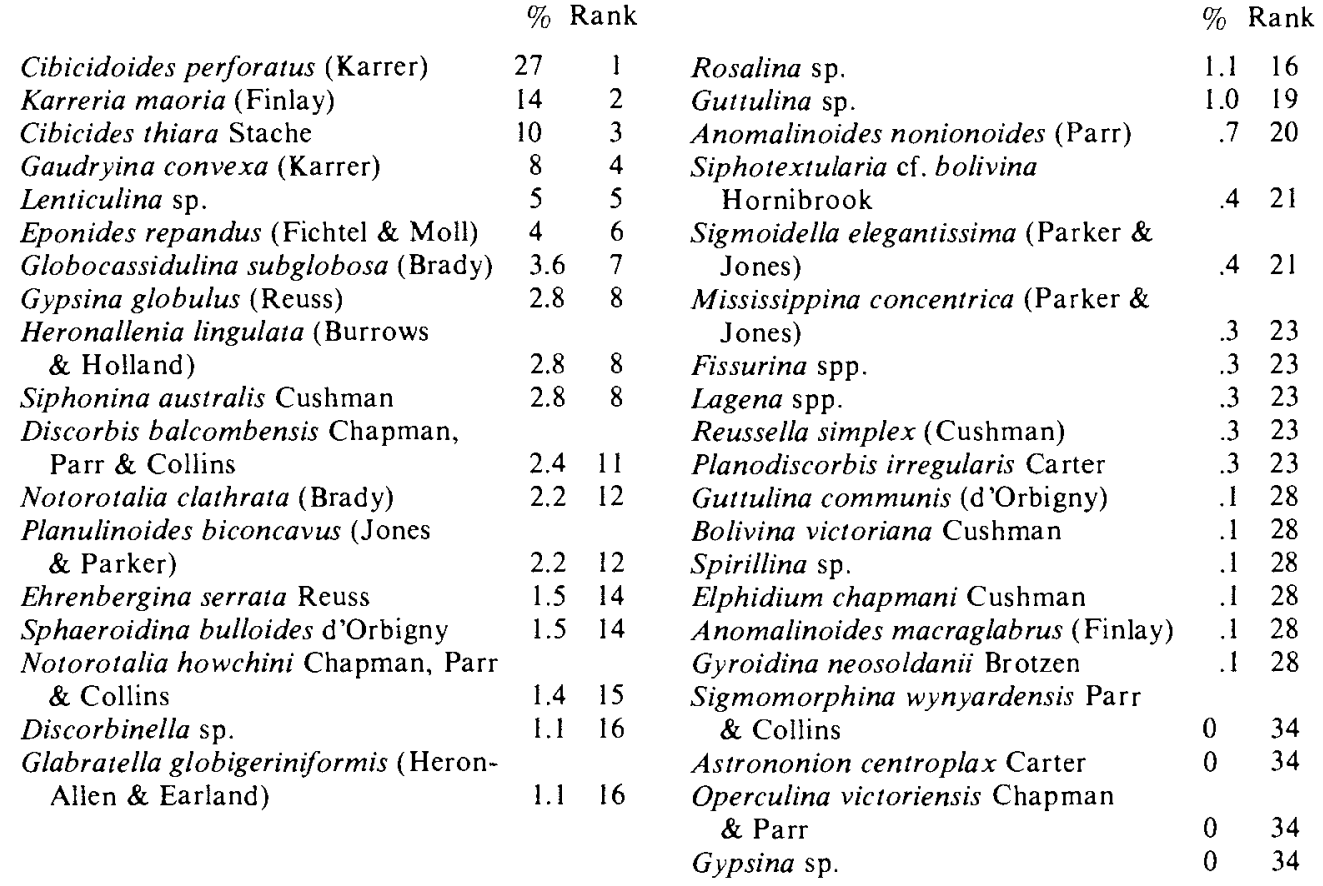

\section{Planktic Foraminiferids}

$\%$ Rank

Globigerina praebulloides group Globigerinita glutinata (Egger)

Globigerina brazieri Jenkins

Globoquadrina dehiscens dehiscens

(Chapman, Parr \& Collins) Globigerina labiacrassata Jenkins

G. woodi woodi Jenkins

$\begin{array}{cc}31 & 1 \\ 25 & 2 \\ 16 & 3 \\ & \\ 14 & 4 \\ 6 & 5 \\ 3.5 & 6\end{array}$

Blow (1969). Therefore the samples are comparable in age with much of the Tertiary along Tasmania's northern and northwestern coast documented by Quilty (1972), but the deeper water aspect shows that the planktic content recorded here represents a greater diversity whereas the earlier studies were on shallower faunas probably of reduced diversity.

\section{Benthic foraminiferid basis.}

Carter in particular has contributed a great deal to the knowledge of the stratigraphic distribu-
Globorotalia nana Bolli

G. zealandica Hornibrook

$G$. rubescens decoraperta Ta kayanagi

\& Saito

$\%$ Rank

$2.5 \quad 7$

1.78

$\begin{array}{lr}.3 & 9 \\ 1 & 10\end{array}$

Globigerinoides quadrilobatus

immaturus Leroy

tion of southeastern Australian benthic foraminiferids (Carter 1958, 1964) and this has been extended by Quilty $(1974,1977,1982)$ to include the Tasmanian species. Key species in Carter's Schemes to be recovered here are Discorbis balcombensis Chapman, Parr and Collins, Notorotalia howchini (Chapman, Parr and Collins), Astrononion centroplax Carter and Operculina victoriensis Chapman and Parr, consistent with assignment to Carter's (1958) Faunal Units 6-8, and also consistent with, but not as precise as, the Early Miocene age identified above on the basis of planktics. 


\section{TABLE 2 \\ SPECIES RECORDED FROM PLIOCENE SEDIMENT}

\section{Benthic Foraminiferids}

$\%$ Rank

\section{Cibicidoides perforatus (Karrer)}

Elphidium crispum (Linnaeus)

Globocassidulina subglobosa (Brady)

Cibicides cicatricosus (Schwager)

Euuvigerina compacta Collins

Cassidulina neocarinata Thalmann

Elphidium imperatrix (Brady)

Textularia sagittula Defrance

Gaudrvina convexa (Karrer)

Ehrenbergina serrata Reuss

Lagena spp.

Cibicidoides mediocris (Finlay)

Elphidium verriculatum (Brady)

Pileolina australensis (Heron-Allen \&

Earland)

Anomalinoides cf. macraglabrus

(Finlay)

Quinqueloculina lamarckiana

d'Orbigny

Lenticulina $\mathrm{sp}$.

Miliolinella subrotunda (Montagu)

Cibicides cf. lobatulus (Walker

\& Jacob)

Guttulina communis (d'Orbigny)

Fissurina spp.

Trifarina bradyi Cushman

Planulina ariminensis d'Orbigny

Osangularia sp.

Textularia sp.

Bolivina alata (Seguenza)

Discorbinella subbertheloti (Cushman)

Pyrgo vespertilio (Schlumberger)

Ouinqueloculina granulosa Natland

Q. laevigata d'Orbigny

Cornuspira incerta (d'Orbigny)
$\%$ Rank.

$.5 \quad 32$

$.5 \quad 32$

$.5 \quad 32$

.532

$\begin{array}{ll}5 & 32\end{array}$

$.4 \quad 38$

$4 \quad 38$

Triloculina trigonula (Lamarck)

Rectobolivina columellaris (Brady)

Cibicidoides pseudoungerianus

(Cushman)

Textularia vertebralis Cushman

Dorothia parri Cushman

Martinottiella sp.

Epistomina elegans (d'Orbigny)

Unidentified miliolid

Spirillina vivipara Ehrenberg

Gavelinopsis lobatulus (Parr)

Glabratella sp.

Astrononion sp.

Quinqueloculina angularis d'Orbigny

Bulimina fijiensis (Cushman)

Spirillina decorata Brady

S. sp.

Pileolina opercularis (d'Orbigny)

Planulinoides biconcavus (Jones

\& Parker)

Planopulvinulina dispansa (Brady)

Clmbaloporetta sp.

Eponides repandus (Fichtel \& Moll) $\quad 2 \quad 50$

Calcarina calcar d'Orbigny $\quad 2 \quad 50$

Pullenia subcarinata (d'Orbigny) $\quad 250$

$\begin{array}{lll}G \text { yroidina broeckhiana (Karrer) } & 2 & 50\end{array}$

Pyrgo depressa (d'Orbigny) $\quad .162$

Marginulina sp.

Pseudopolymorphina sp.

$0 \quad 63$

$0 \quad 63$

\section{Planktic Foraminiferids}

Globorotalia inflata (d'Orbigny) small globigerinids

Globigerina bulloides bulloides d'Orbigny

Globorotalia acostaensis acostaensis Blow

G. scitula scitula (Brady)

Globigerina rubescens decoraperta

Takayanagi \& Saito

Globigerinita $\mathrm{sp}$

G. quinqueloba (Natland)

G. sp. indet.
$\%$ Rank.

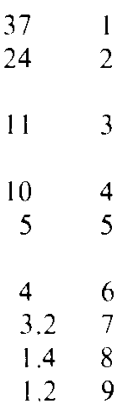

Globorotalia obesa Bolli

$G$. crassula crassula Cushman \& Stewart

Orbulina universa d'Orbigny

Globigerina falconensis $\mathrm{Blow}$

Globorotalia crassaformis (Galloway

\& Wissler)

Globigerinita incrusta Akers

Globorotalia conomiozea mons

Hornibrook

Hastigerina pelagica d'Orbigny

Globorotalia hirsuta praehirsuta Blow
$\%$ Rank.

1.29

$\begin{array}{ll}6 & 11\end{array}$

$\begin{array}{ll}.5 & 12\end{array}$

$.4 \quad 13$

$\begin{array}{ll}3 & 14\end{array}$

215

$\begin{array}{ll}2 & 15\end{array}$

115

117 


\section{Environment of Deposition}

\section{Depth}

Planktic foraminiferids comprise $62 \%$ of the total fa una, suggesting a middle to outer continental shelf regime. The absence of large shallow water benthics (such as Amphistegina, Planorbulinella spp., Sherbornina) all are inconsistent with an inner shelf origin. The high diversity (19 species making up $95 \%$ of the benthic fauna) and moderate dominance (percentage of the fauna consisting of the dominant species - 27) are consistent with the planktic indications. The low proportion of buliminids, presence of very rare shallow species (e.g Operculina victoriensis) and presence of large numbers of an attached form such as Karreria maoria (Finlay) would suggest a shallower origin than outer shelf. Perhaps overall, the indicators suggest a middle shelf origin, say approximately $100-150 \mathrm{~m}$.

There are about 265 foraminiferids per gram of sediment.

\section{Temperature}

The presence of Operculina victoriensis and Gypsina globulus suggests that the benthic forms occupied warm temperate waters or warmer. This is in contrast with the planktic indicators.

There are no keeled globorotalids, consistent with the results elsewhere around Tasmania for faunas of this age (Quilty 1972). The total planktic fauna consists of nine species and subspecies and thus although numerically large, has a diversity similar to that in modern cool temperate faunas. Bandy (1964) would suggest that the presence of non-keeled globorotalids would occur in water temperatures of $9-17^{\circ} \mathrm{C}$. The very low numbers would indicate the lower part of that temperature range.

\section{Other aspects of the enviornment.}

All other indications are that normal open ocean conditions applied.

\section{Yellowish, coarse-grained calcarenite (Sample 2 above)}

\section{Age}

\section{Planktic foraminiferid basis.}

Jenkins (1971), Kennett and Vella (1975) and Srinivasan and Kennett ( 198 la, b) have provided a basis for comparison of the faunas from the new samples with deeper water, more complete sections. In addition the monumental work by Blow (1969) has provided a useful foundation.

This sample contains abundant planktic foraminiferids, dominated by Globorotalia inflata. (Also present are $G$. acostaensis acostaensis, $G$. conomiozea mons, G. crassaformis, G. hirsuta praehirsuta, Globigerina rubescens decoraperta and many other species (see table 2) not diagnostic of age at this level. All these determinations (other than Globorotalia conomiozea mons) a re consistent with the Late Pliocene faunas recorded by Srinivasan and Kennett from DSDP Site 281. Srinivasan and Kennett (1981b, fig. 8) summarised all the available data and in that scheme, the present samples clearly correlate best with the mid Pliocene, Globorotalia crassaformis Zone, approximately N20. G. $r$. decoraperta is transitional to $G$. $r$. rubescens perhaps also consistent with an N20 age.

In the scheme proposed by Hornibrook (1982) for DSDP Site 284, the correlation would suggest an older age ( $G$. puncticulata or $G$. margaritae Zones) if the apparently anomalous early appearance of $G$. inflata is ignored. If $G$. $c$. mons is ignored, all schemes become compatible and the age can be taken as mid-Pliocene. Blow's (1969) and Jenkins' (1971) works do not allow an age determination more precise than "Pliocene" This appears to be the first foraminiferid-based Pliocene age documented from Tasmania.

As important in this context as the species present, are those not known in the sample. Despite detailed searching, there is no evidence of Globorotalia truncatulinoides d'Orbigny or any sphaeroidinellids or pulleniatinids. Globigerinoides also is absent.

\section{Benthic foraminiferid basis.}

Much of the development of Australian Stage terminology is based on the study of molluses and benthic foraminiferids. Molluscs are common in this sediment but have not been studied. Benthic foraminiferids are abundant but seem to be of a deeper water facies than usually encountered in the Australian Pliocene known so far, and thus age diagnostic forms are absent.

\section{Environment of Deposition}

\section{Depth}

The fauna contains $53 \%$ planktic forms and thus can be regarded as a middle continental shelf fauna. This figure probably is lower than it should be because the sediment shows considerable evidence of winnowing. Dominance is $25 \%$ and diversity about 40 , roughly consistent with middle to inner shelf values as developed in the Gulf of Mexico (Walton 1964). The higher content of buliminacean species suggests water a little deeper than for the Early Miocene sample. There are no shallow water indicators. The sediment probably accumulated near or a little over the continental shelf edge, perhaps in a situation and under conditions similar to those where the samples were taken. 


\section{Temperature}

Water temperature was probably higher than in the Early Miocene of the vicinity. Only the Lepidocyclina limestone of northwestern Tasmania (Quilty 1972) would represent considerably warmer Tertiary conditions in Tasmania. The planktic fauna includes keeled Globorotalia spp such as $G$. conomiozea mons, $G$. crassula crassula and $G$. hirsuta praehirsuta, although all are uncommon suggesting that waters may have been cool to warm temperate. As noted earlier other significant warm water groups are absent. Very warm water indices are absent.

Deposition of this mid-Pliocene sediment probably coincided approximately with the Kalimnan of southeastern Australia (approximately N19-early N20; Abele et al. in Douglas and Ferguson 1976), although of a much deeper water deposition than the stratotype Kalimnan. There is no benthic basis for correlation between the two sections. As the stratotype Kalimnan probably represents sedimentation at a sea-level high coinciding with the last relatively warm-water period, and immediately prior to a major fall in sea level, this mid-Pliocene sediment is likely to be of a (relatively) warmer-water aspect than any forming in this location since.

According to Shackleton and Kennett (1975) the Late Pliocene was an interval of notably depressed surface water temperatures coinciding with a sea-level low of the order of $50 \mathrm{~m}$ below present level following a mid-Pliocene high stand probably also coinciding with the last warm water episode before the onset of Pleistocene glaciation. Shackleton and Kennett performed their analyses from DSDP sites on the Pacific plate but no analyses of any significance are available from closer localities particularly from the Indian Australian plate. Between the Early Miocene and Late Pliocene (some 18-19 million years), Australia had moved north some $1200 \mathrm{~km}$, consistent in a general way with increasing sea water temperature.

\section{CONCLUSIONS}

Early Miocene and mid-Pliocene marine sediments have been identified from new localities. The Early Miocene sediments are an extension of sedimentary sequences well known from elsewhere around northern Tasmania but mid-Pliocene sediments are not known elsewhere in Tasmania and the environment of deposition has not been recorded in southeastern Australia before.

\section{ACKNOWLEDGEMENTS}

My main debt is to Mr Robert Green who had the presence of mind to retain the samples fortuitously dredged. Lesley Manson and Maree Pedder typed the manuscript and Bruce Hill drafted the figures. Gerry Nash was responsible for the electron microscope photography.

\section{REFERENCES}

BANDY, O.L., 1964: Cenozoic planktonic foraminiferal zonation. Micropaleontology, 10: 1-17.

BLOW, W.H., 1969: Late Middle Eocene to Recent planktonic foraminiferal biostratigraphy. Proc. Ist Intern'l Conf. Planktonic Microfossils. Geneva 1: 199-422.

CARTER, A.N., 1958: Tertiary foraminifera from the Aire district, Victoria, Bull.geol.Surv.Vict., 55: $1-76$.

CARTER, A.N., 1964: Tertia ry foraminifera from Gippsland, Victoria and their stratigraphical significance. Mem.geol.Surv.Vict., 23: 1-154.

DEIGHTON, L., FALVEY, D.A., \& TAYLOR, D.J. 1976: Depositional environments and geotectonic frame work: southern Australian continental margin. Aust. Petrol.Explor.Assoc. J., 16: 25-36.

DOUGLAS, J.G., and FERGUSON, J.A., 1976: THE GEOLOGY OF VICTORIA. Spec. Publn. Geol. Soc. Aust. 5: 1-528.

EDWARDS, A.R., 1975: Southwest Pacific Neogene palaeogeography and an integrated Neogene paleo-circulation model. In ANDREWS, J.E., PACKHAM, G., et al., 1975. Initial reports of the Deep Sea Drilling Project, 30: 667-684. U.S Government Printing Office, Washington.

HOR NIBROOK, N.deB., 1961: Tertiary foraminifera from the Oamaru district (N.Z.) Geol.Surv.N.Z., Pal. Bull. 34(1): 1-194.

HORNIBROOK, N.deB., 1982: Late Miocene to Pleistocene Globorotalia (Foraminiferida) from DSDP Leg 29, Site 284, southwest Pacific. N.Z.J. Geol.Geophys., 25: 83-99

JENKINS, D.G., 1971: New Zealand Cenozoic planktonic foraminifera. Geol.Surv.N.Z., Pal.Bull. 42: $1-278$.

KENNETT, J.P., HOUTZ, R.E, ANDREWS, P.B. $e$ al., 1975: Cenozoic paleoceanography in the southwest Pacific Ocean, Antarctic glaciation, and the development of the circum-Antarctic current. In KENNETT, J.P., HOUTZ, R.E. et al. 1975. Initial Reports of the Deep Sea Drilling Project - 29: 1155-1169 U.S. Govt. Printing Office, Washington.

KENNETT, J.P., \& SRINIVASAN, M.S., 1984: NEOGENE PLANKTONIC FORAMINIFERA. Hutchinson Ross Publishing Co.; Stroudsburg.

KENNETT, J.P., \& VELLA, P. I975: Late Cenozoic planktonic foraminifera and pala eoceanography at DSDP Site 284 in the cool subtropical south Pacific. In KENNETT, J.P., HOUTZ, R.E. et al. 1975: Initial Reports of the Deep Sea Drilling Project, 29: 769-799. U.S. Govt. Printing Office, Washington. 
QUILTY, P.G., 1972: The biostratigraphy of the Tasmanian Marine Tertiary, Pap. Proc. R.Soc.Tasm. 106: 25-44.

QUILTY, P.G., 1974: Tasmanian Tertiary foraminifera. Part 1. Textularina, Miliolina, Nodosariacea Pap.Proc.R.Soc.Tasm., 108: 31-106.

QUILTY, P.G., 1977: The same. Part 2. chiefly Spirillinacea to Glabratellidae. ibid., 111: 69-109

QUILTY, P.G., 1982: Tasmanian Tertiary foraminifera. Part 3. Discorbacea (Eponididae) to Nonionacea. Pap.Proc.R.Soc. Tasm., 116: 5-52.

SHACKLETON, N.J., \& KENNETT, J.P., 1975: Late Cenozoic oxygen and carbon isotopic changes at DSDP Site 284: implications for glacial history of the northern hemisphere and Antarctica. In KENNETT, J.P., HOUTZ, R.E., et al. Initial reports of the Deep Sea Drilling Project, 29 801-807. U.S. Govt. Printing Office, Washington.
SRINIVASAN, M.S, \& KENNETT, J.P., 1981a: A review of Neogene planktonic foraminiferal biostratigraphy: applications in the equatorial and south Pacific. Spec.Publ.Soc.econ.Paleont. Miner. 32: 295-432.

SRINIVASAN, M.S.,\& KENNETT, J.P., 1981 b: Neogene planktonic foraminiferal biostratigraphy and evolution: equatorial to subantarctic, South Pacific. Marine Micropaleont., 6: 499-533.

WALTON, W.R., 1964: Recent foraminiferal ecology and paleoecology. In IMBRIEJ., and NEWELL, N., 1964. APPROACHES TO PALEOECO$L O G Y$ : 15 l-237. Wiley \& Sons, New York.

(accepted May 1, 1985)

\section{PLATE 1 \\ MIOCENE PLANKTIC FORAMINIFERIDS}

FIG. 1,8 - Globigerina brazieri Jenkins; 1. ventral view, $x 85$. UTGD $122680 ; 8$. dorsal, x 85. UTGD 122680 .

FIG. 2,3-G. woodi connecta Jenkins; 2 . ventral x 210; 3. dorsal, x 160. UTGD 122681.

FIG. 4 - G. labiacrassata Jenkins; 2 . ventral x 210; 3. dorsal, x 160. UTGD 122681.

FIG. 5,6-G. woodi woodi Jenkins; 5. ventral, $\mathrm{x}$ $85 ; 6$. dorsal, x 100. UTGD 122683 .

FIG. 7 - G. rubescens decoraperta (Taka ya nagi and Saito); oblique ventral view, x 110 . UTGD 122684.
FIG. 9 - Globigerinoides quadrilobatus immaturus LeRoy; dorsal view, x 100. UTGD 122685.

FIG. 10 - Globigerinita glutinata (Egger); ventral view, x 150. UTGD 122686.

FIG. 11-13-Globoquadrina dehiscens dehiscens (Chapman, Parr and Collins); 11 . ventral x 85; 12 . detail of aperture, $x 350 ; 13$. dorsal' $x$ 105. UTGD 122687.

FIG. 14, 15-Globorotalia zealandica Hornibrook; 14. ventral, x 195; 15. dorsal, x 170. UTGD 122688.

\section{PLATE 2 \\ PLIOCENE PLANKTIC FORAMINIFERIDS}

FIG. 1-Globorotalia (Truncorotalia) acostaensis acostaensis Blow; ventral view, x 130 . UTGD 122689 .

FIG. 2 - Globigerina falconensis Blow; ventral view, x 150. UTGD 122690.

FIG. 3 - Globigerinita incrusta Akers; ventral view, x 195. UTGD 122691.

FIG. 4 - Turborotalita quinqueloba (Natland); ventral view, x 170. UTGD 122692.

FIG. 5,6-Globorotalia (Hirsutella) scitula scitula (Brady); 5. ventral, x 115;6. dorsal, x 150. UTGD 122693 .

FIG. 7,8-G. (Truncorotalia) inflata (d'Orbigny); 7. ventral, x 90; 8. dorsal, x 80. UTGD 122694.
FIG. $9,10-G$. (Truncorotalia) crassaformis (Galloway \& Wissler); 9. ventral, $x$ 85; 10. dorsal, $x$ 100. UTGD 122695 .

FIG. 11,12-G. (Hirsutella) hirsuta praehirsuta Blow, 11 . ventral, x 50; 12. dorsal, x 65. UTGD 122696.

FIG. 13,14 - G. (Truncorotalia) conomiozea mons Hornibrook; 13. dorsal, x 140; 14. a pertural, x 130. UTGD 122697.

FIG. 15-16 - G. (Truncorotalia) c. crassula Cushman and Stewart; 15. ventral, x 135; 16. dorsal, x 145. UTGD 122698. 
100 Patrick G. Quilty.
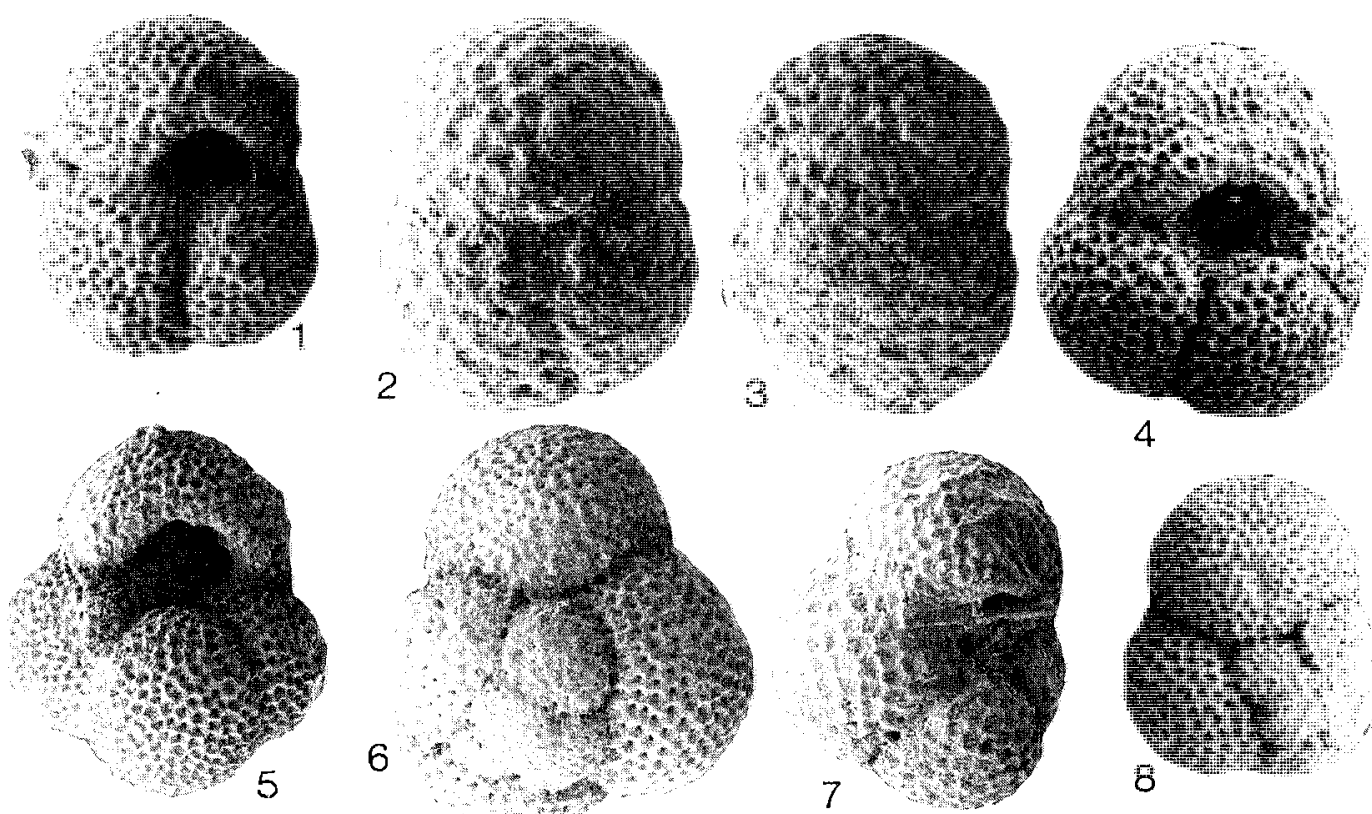

6
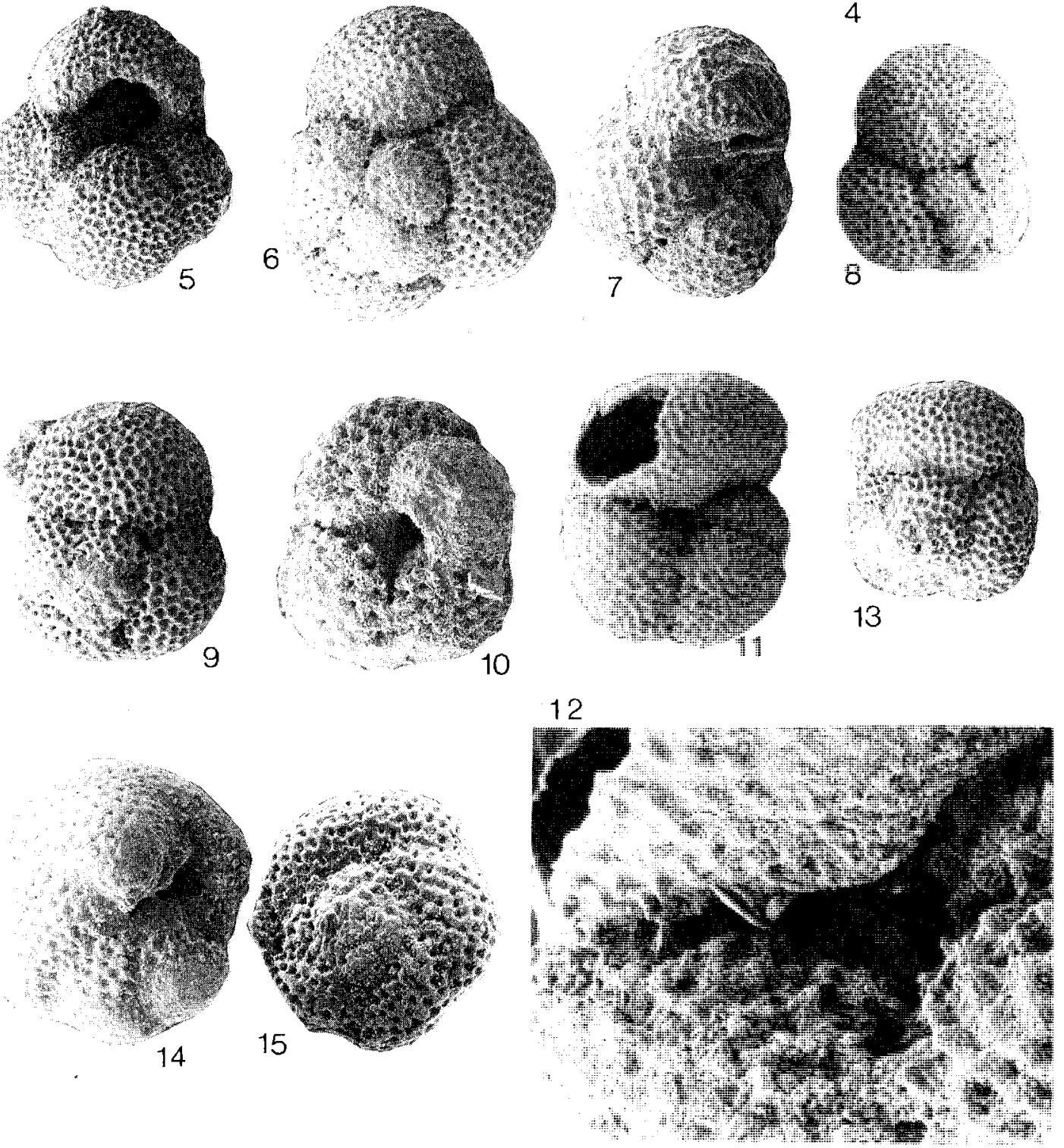

PLATE 1 

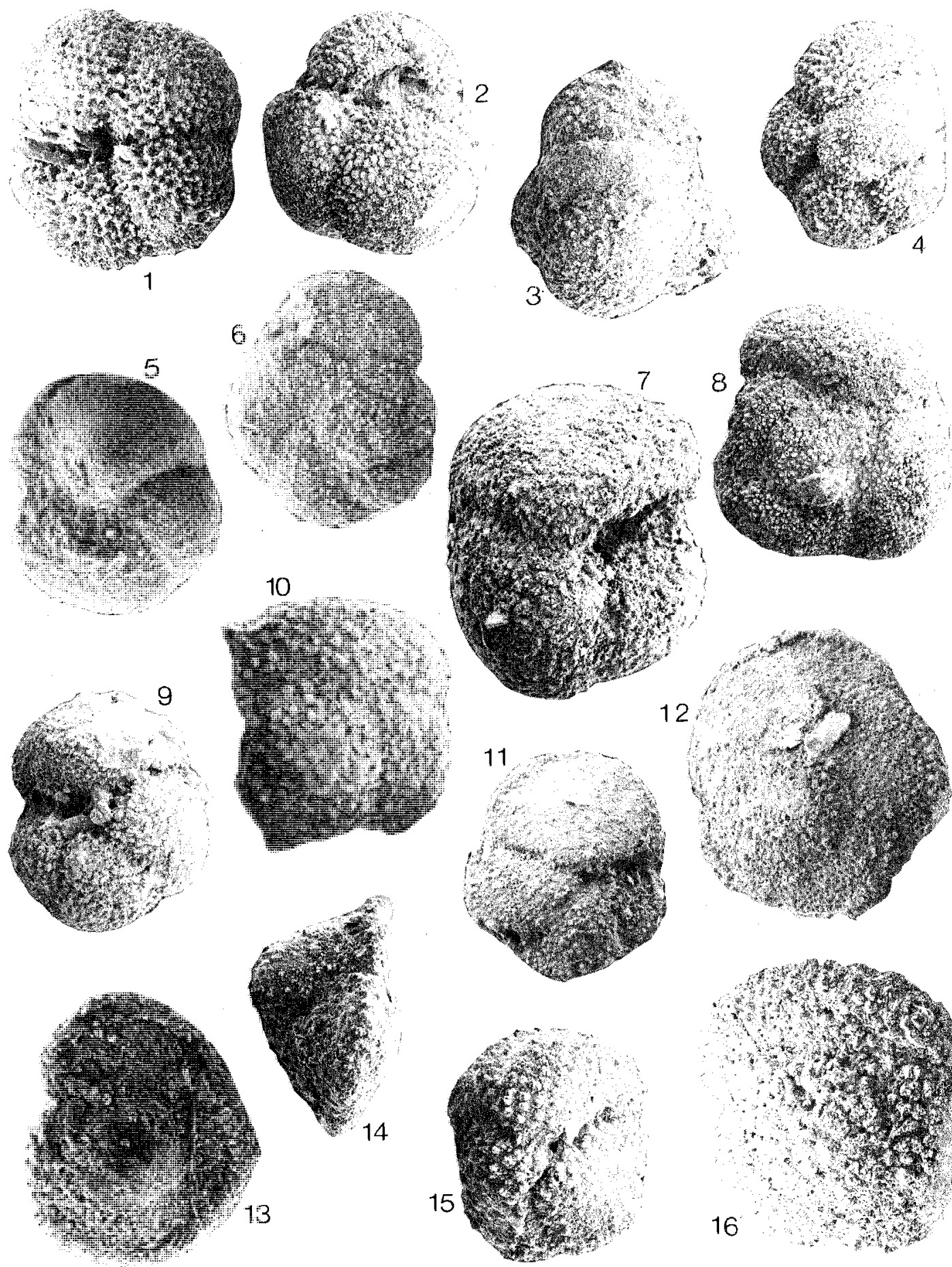

12
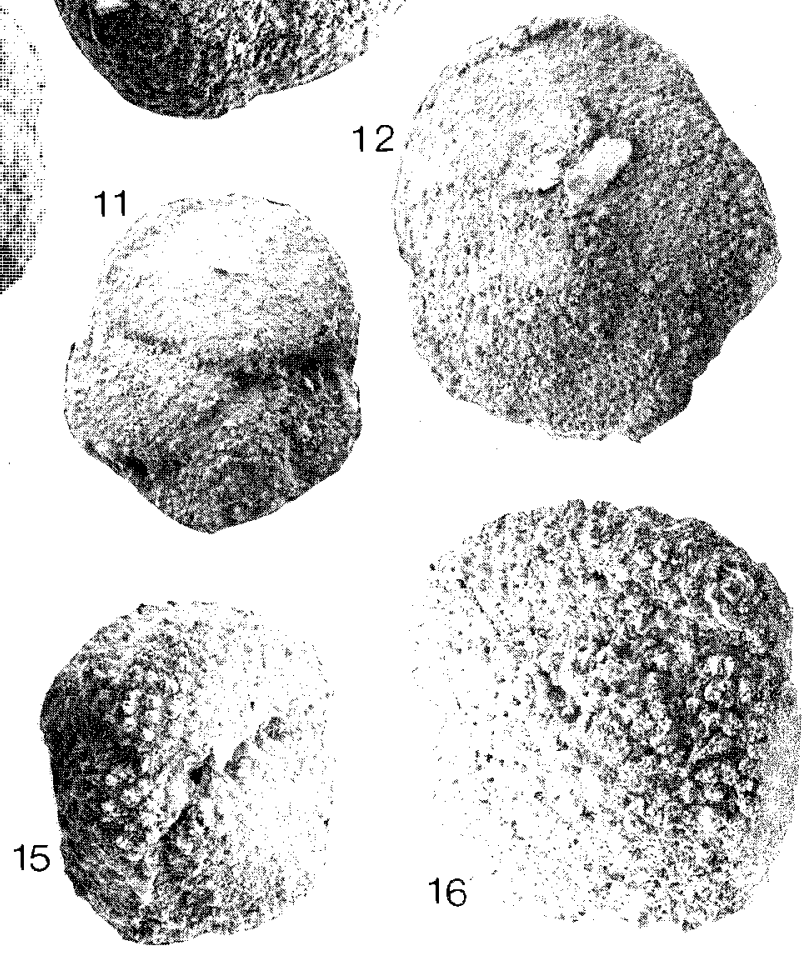

PLATE 2 